\title{
Preprint \\ Short Report: a damaging downslope wind storm in western Wales $1-2$ March 2018
}

\author{
David Smart ${ }^{1}$ \\ UCL Hazard Centre, University College London \\ Accepted at Weather September 2019 \\ WEA-19-0051
}

\begin{abstract}
Sustained, strong and damaging wind gusts affecting the coastal region of western Wales overnight 1-2 March 2018. Using output from a weather forecast model the origin of the strong winds is attributed to a turbulent downslope wind storm to the lee of the Welsh mountains in an easterly flow regime.
\end{abstract}

Overnight on 1-2 March 2018 western Wales experienced a prolonged period of extremely strong and gusty easterly winds resulting in disruption to the transport infrastructure, power cuts, damage to properties and the felling of trees. Damage to roofs of homes in the coastal town of Tywyn was extensive and the roof of the local leisure centre torn off (BBC News, 2018a). Although the precise circumstances are unclear (John Mason, pers. comm.) many boats were severely damaged, some sunk, in gale force winds at the sheltered Holyhead marina, Anglesey (BBC News, 2018b). Anecdotally, winds were reported to have reached $80 \mathrm{mph}\left(70 \mathrm{kn}, 36 \mathrm{~ms}^{-1}\right)$ at the marina. The strong winds were accompanied by heavy snowfall and severe cold across much of Wales and England (see the special issue of Weather vol. 74, March 2019).

Table 1 shows the strongest winds on 2 March obtained from a search of weather station records. All the strongest winds were observed at stations to the lee of the Welsh mountains on the Welsh coast and hinterland. Gusts in excess of 38 knots (44 mph, 19 $\mathrm{ms}^{-1}$ ) were consistently observed from the early evening of the $1^{\text {st }}$ to mid-morning of the $2^{\text {nd }}$ although the variation in speed was highly erratic (not shown). Gusts at Tywyn appeared to have peaked near 06 UTC at 68 knots $\left(78 \mathrm{mph}, 35 \mathrm{~ms}^{-1}\right)$. The wind direction was generally easterly, although at Tywyn gusts tended to back north-easterly. Gust ratios at the lowland coastal stations were typically $\sim 1.5$, however ratios at higher elevations were closer to 2 . The strongest winds appear to have abated by mid-day on the $2^{\text {nd }}$. Mean winds and gusts recorded at the NERC (National Environmental Research Council) facilities outside of Aberystwyth were not notable although some damage was reported in the town itself.

The synoptic background to this event will not be discussed in detail here but features of note include a blocking anticyclone over Scandinavia and a low pressure system in Biscay moving poleward with a centre lying in the western Channel by 12 UTC 2 March. This resulted in a tightening pressure gradient and a cold, easterly flow over south-west England and Wales overnight 1-2 March. The question arises as to the origin of the strongest wind gusts and to answer this a brief analysis of mesoscale forecast model output was undertaken.

The model used was an up-to-date version of the WRF (Weather Research and Fore casting) model initialised with GFS (Global Forecast System) data. The high-resolution

1 Correspondence: D J Smart, UCL Hazard Centre, Kathleen Lonsdale Building, Gower Place, London, WC1 6B, UK. Email: d.smart@ucl.ac.uk 
domain had a grid spacing of $3 \mathrm{~km}$ in the horizontal and 51 levels in the vertical. The model physics package included a full set of parametrisations. Figure 1 shows a $300 \mathrm{~km}$ long west-east cross-section of part of the $3 \mathrm{~km}$ grid roughly centred on Aberystwyth. Striking features of this plot include a deep mountain wave over the Welsh mountains with a couplet of strong ascent and descent (exceeding $+0.5 /-1.5 \mathrm{~ms}^{-1}$ ) resulting in cloud clearance (low relative humidity) above the mountain and a $40 \mathrm{~ms}^{-1}$ wind speed maximum just above the lee slopes. The bold green contour delineates where the Richardson number $(\mathrm{Ri})$ equals 0.25 . Low values of $\mathrm{Ri}(<1)$ near the ground are associated with a significant risk of severe turbulence resulting in the transport of high momentum air to the surface in the form of turbulent wind gusts, see for example Stull (1988), p175-179. Indeed a model gust diagnostic exhibits extensive areas of gusts $>35 \mathrm{~ms}^{-1}$ west of the Cambrian mountains (not shown).

In summary a case of strong damaging wind gusts in a cold, easterly flow regime over the Welsh mountains has been examined. This brief study suggests they were the result of a downslope wind storm associated with a mountain wave. Following the pioneering work of Manley (Manley, 1945; Veale and Endfield, 2014) on the 'Helm Wind' there have been a number of studies of stably stratified easterly flow over the Pennines in northern England. A non-exhaustive search of the literature suggests easterly downslope wind storms in the lee of the Cambrian range are a less well-documented and possibly unusual phenomenon.

\section{Acknowledgements}

The author thanks John Mason (Machynlleth, Powys) for discussions and help with gathering and assessing damage reports. Discussions with Prof Keith Browning are also gratefully acknowledged.

\section{References}

BBC News, 2018a. "Storm Emma: Snow brings power cuts and travel chaos", http://www.bbc.co.uk/news/uk-wales-43250636, accessed 08/04/2019.

BBC News, 2018b. "Storm Emma smashes boats at Holyhead marina, Anglesey", http://www.bbc.co.uk/news/uk-wales-north-west-wales-43257319, accessed 08/04/2019.

Lucy Veale and Georgina Endfield, The Helm Wind of Cross Fell, Weather, 69, 1, (37), (2014).

Manley, G. (1945), The helm wind of Cross Fell, 1937-1939. Q.J.R. Meteorol. Soc., 71: 197-219.

Stull, R. (1988). An introduction to boundary layer meteorology. Kluwer Academic Publishers, Dordrecht. 


\begin{tabular}{|c|c|c|c|c|c|}
\hline Location & $\begin{array}{l}\text { Time of peak } \\
\text { gust } \\
2 \text { March (UTC) }\end{array}$ & $\begin{array}{c}\text { Mean } \\
\text { windspeed } \\
\text { ms }^{-1} \\
(\mathbf{m p h}) \\
\end{array}$ & $\begin{array}{l}\text { Max gust } \\
\text { ms }^{-1} \\
\text { (mph) }\end{array}$ & $\begin{array}{l}\text { Gust } \\
\text { ratio }\end{array}$ & Comments \\
\hline Tywyn & 547 & $22(49)$ & $35(78)$ & 1.59 & Gusts tending to back NEly from ESEly \\
\hline Caernarfon & 0 & $17(38)$ & $34(76)$ & 2 & $\begin{array}{c}\text { CWOP } 53.07 \mathrm{~N}-4.23 \mathrm{~W} \text {, alt. } 304 \mathrm{~m} \text {. } \\
\text { Gusts above } 50 \text { mph overnight to mid- } \\
\text { day }\end{array}$ \\
\hline Nantile & 500 & $14(31)$ & $29(65)$ & 2.07 & $\begin{array}{l}\text { CWOP } 53.05 \text { N } 4.24 \mathrm{~W} \text {, alt.108 m. } \\
\text { Gusts above } 44 \text { mph overnight to mid- } \\
\text { day }\end{array}$ \\
\hline Aberdaron & 300 & $20(45)$ & $29(65)$ & 1.45 & $\begin{array}{c}\text { Gusts above } 31 \text { mph overnight to mid- } \\
\text { day }\end{array}$ \\
\hline RAF Valley & 300 & $19(43)$ & $29(65)$ & 1.53 & Anglesey \\
\hline RAF Mona & 1100 & $18(40)$ & $25(56)$ & 1.39 & $\begin{array}{l}\text { Anglesey. Gusts above } 43 \mathrm{mph} \\
\text { overnight to mid-day }\end{array}$ \\
\hline Aberporth & 100 & $13(29)$ & $22(49)$ & 1.69 & \\
\hline
\end{tabular}

Table 1: Selected observations of maximum gust speeds from western Wales on 2 March 2018. CWOP- Citizen Weather Observer Program station. Source: http://weatherobs.com/ (accessed 03/03/2018).

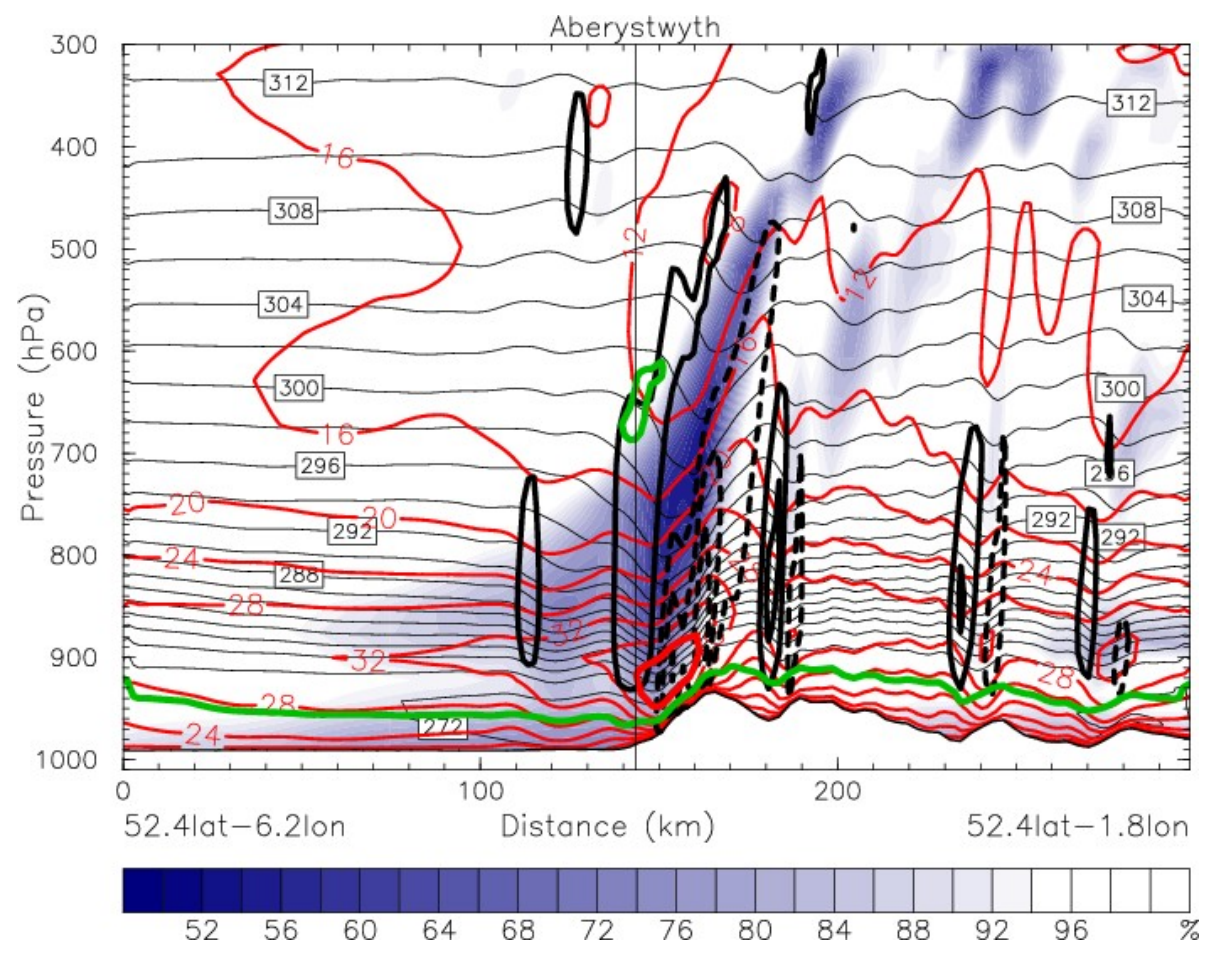

Figure 1: Model cross-section at the latitude of Aberystwyth from a $T+12 \mathrm{~h}$ forecast valid at 06 UTC 2 March. Relative humidity (\%) shaded according to colour scale; dry-bulb potential temperature $(\mathrm{K})$ thin, black contours; horizontal windspeed $\left(\mathrm{ms}^{-1}\right)$ red contours, $40 \mathrm{~ms}^{-1}$ isotach highlighted in bold; vertical velocity $\left(\mathrm{cm} \mathrm{s}^{-1}\right)$ bold black contours every 50 $\mathrm{cm} \mathrm{s}^{-1}$, descent dashed; Richardson number $=0.25$ green contour. The location of Aberystwyth in the plane of the cross-section is indicated by the vertical line. 